a glównie newralgiczne kwestie, zawierające inwokacje do przeszłości, jak np.:

- mity polityczne a pedagogika;

- pytania o funkcje szkoly w sytuacji chaosu politycznego;

- ustrojowe przeobrażenia selekcji szkolnych;

- demokratyzacja oświaty gdańskiej itp.

Stosowne referaty wygłosili: Ryszard Jadczak, Zbigniew Kwieciński, Ryszard Borowicz, Lech Mokrzecki, Bronisław Siemieniecki, Danuta Koźmian, Roman Tomaszewski, Wiesław Theiss, Witold Wojdyło, Dorota Żołądż-Strzelczyk, Wiesław Jamrożek, Piotr Zwierzchowski, Aleksandra Norkowska, Krzysztof Jakubiak, Michał Strzelecki, Henryk Składanowski, Grzegorz Radomski, Stefania Walasek $\mathrm{i}$ in.

Usłyszeliśmy także dwa wystąpienia gości zagranicznych z zaprzyjaźnionego z UMK Uniwersytetu Carla von Ossietzky'ego w Oldenburgu (RFN). Referat pt.: Schulkonflikte im von Preussen beherschten Teil Polens in der 2 Hälfte des 19. Jahrhunderts wygłosil prof. dr Klaus Klattenhoff, zaś prof. dr Frierdrich Wissmann omówił temat: Schule im Dienste der Volkstum-

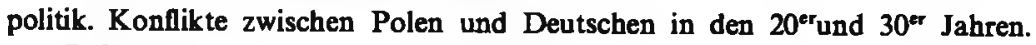

Referaty te $w$ istotny sposób korespondowały z programem konferencji i dały dowód coraz szerszego zainteresowania się polską problematyką historyczno-pedagogiczną przez niemieckich badaczy.

Zaprezentowana w referatach różnorodność problematyki i profesjonalność podejścia do niej ukazała także wielowarstwowe kwestie metodologiczne, które wzajemnie się zazębiając wzbogacały ukazywane warsztaty metodologiczne.

Interesujące będzie wydanie materiałów z konferencji, których społeczność naukowa oczekuje.

Jan Hellwig

\title{
Spuścizna naukowa prof. dra hab. Bogdana Suchodolskiego - tematem sesji naukowej. Uniwersytet Śląski w Katowicach 10.04.1997
}

Zmarły 2 pażdziernika 1992 r. nestor polskiej pedagogiki prof. dr hab. Bogdan Suchodolski wyrażając swą ostatnią wolę przekazał Bibliotece Głównej Uniwersytetu Śląskiego w Katowicach swój znacznych rozmiarów księgozbiór. Uniwersytet Śląski okazując swą wdzięczność Profesorowi podjął uchwałe o nadaniu jednej czytelni Biblioteki Glównej imienia prof. dra hab. Bogdana Suchodolskiego. Z tej okazji odbyła się w dniu 10 kwietnia 1997 r, w auli im. Kazimierza Lepszego Uniwersytetu Śląskiego sesja naukowa a także uroczyste odslonięcie tablicy pamiątkowej poświęconej Profesorowi.

Sesja zgromadziła liczne grono uczniów i współpracowników Profesora. Kilku z nich wystapiło $\mathrm{z}$ referatami naukowymi.

Sesje otworzyła dr hab. Wladyslawa Luszczyk, dziekan Wydziału Pedagogiki i Psychologii, a slowo wstepne wygłosil JM Rektor UŚ, prof. dr hab. Tadeusz Sławek.

W pierwszej części sesji, z udziałem młodzieży akademickiej, referaty wygłosili: prof. dr hab. Zbigniew Kwieciński, dziekan Wydziału Studiów Edukacyjnych Uniwersytetu im. Adama Mickiewicza w Poznaniu i Przewodniczący Polskiego Towarzystwa Pedagogicznego pt: Mądrość jako oferta czwartej pedagogiki pierwszego pedagoga; prof. dr hab. Irena Wojnar z Uniwersytetu 
Warszawskiego pt: Wychowanie dla alternatywnej przyszłości (strategia, legendy i wizje) oraz doc. dr Zygmunt Lomny z Uniwersytetu Opolskiego pt: Profesora Bogdana Suchodolskiego idea edukacji alternatywnej, humanistycznej i naprawy świata.

W części drugiej wspomnienie zatytułowane: Tworzenie przyszłości - historia jednej szkoły, przedstawil prof. dr hab. Ryszard Lukaszewicz z Uniwersytetu Wrocławskiego. Referat pt: Wkład Profesora Bogdana Suchodolskiego do historii wychowania wygłosił prof. dr hab. Jan Hellwig z Uniwersytetu im. Adama Mickiewicza w Poznaniu.

Końcowym akcentem sesji było zaprezentowanie przez mgr Marię Gacińską z Biblioteki Glównej UŚ księgozbioru Profesora Suchodolskiego jako komponentu Biblioteki Głównej tegoż Uniwersytetu.

Uczestnicy przeszli do budynku Biblioteki, gdzie w czytelni Rektor wraz z dyrektorem Biblioteki mgr Wanda Dziadkiewicz dokonali uroczystego odsłonięcia tablicy pamiątkowej oraz nadania tej czytelni imienia Profesora.

Głównymi organizatorami uroczystości był Wydzial Pedagogiki i Psychologii US์ oraz Biblioteka Główna tegoż uniwersytetu.

Jan Hellwig

\section{Zapowiedzi}

\section{Gdańsk - 19-21 września 1997}

Instytut Pedagogiki Uniwersytetu Gdańskiego przy współudziale Instytutu Filozofii i Socjologii UG oraz Nadbaltyckiego Centrum Kultury w Gdańsku: międzynarodowa konferencja nt. „Edukacja i kultura”.

Przewidywane są dwa bloki tematyczne:

- historyczny (od okresu odrodzenia);

- poświęcony współczesności.

\section{Gdańsk - 25-27 września 1997}

Nadbałtyckie Centrum Kultury. Ratusz Staromiejski w Gdańsku: sesja naukowa nt. „Rodzina pomorska".

Szczegółowa tematyka:

- tożsamość kulturowo-etniczna Pomorzan;

- rodzina pomorska w przekazie pamiętnikarskim;

- historia pomorskich rodów;

- tradycje zawodowe rodzin pomorskich;

- studium porównawcze rodziny pomorskiej, wielkopolskiej i śląskiej;

- przemiany współczesnej rodziny pomorskiej.

\section{Poznań-Zajączkowo - 20-22 października 1997}

Zakład Historii Wychowania UAM: konferencja naukowa nt. „Rola i miejsce kobiet w edukacji i kulturze polskiej (od średniowiecza do czasów współczesnych)". 